Gut, 1989, 30, 1339-1343

\title{
Glycoprotein synthesis and secretion by cultured small intestinal mucosa in coeliac disease
}

\author{
J E CRABTREE, R V HEATLEY, AND M S LOSOWSKY \\ From the Department of Medicine, St James's University Hospital, Leeds
}

\begin{abstract}
SUMmARY Glycoprotein biosynthesis by jejunal mucosa was examined during culture in vitro in 26 patients with coeliac disease and 19 controls. The incorporation rates of tritiated glucosamine into tissue and secreted glycoproteins were determined using established techniques. The total glucosamine incorporation in untreated coeliac patients was significantly greater than that of histologically normal mucosa $(p<0 \cdot 001)$ and jejunal tissue from patients with treated coeliac disease $(\mathbf{p}<\mathbf{0} \cdot 01)$. Enhanced secretion of in vitro labelled glycoproteins was observed in untreated coeliac patients. The total incorporation of tritiated glucosamine in intestinal tissues was correlated with goblet cell numbers. These results indicate that quantitative changes in glycoprotein synthesis and secretion occur in coeliac disease.
\end{abstract}

In coeliac disease many immunological, biochemical, and morphological changes are evident in the jejunal mucosa of patients with villous atrophy. Specific abnormalities associated with the epithelium include changes in enterocyte structure,' brush border enzyme activity," crypt cell production rate" and HLA antigen expression. ${ }^{4}$ Little, however, is known about goblet cell function in coeliac disease and, surprisingly, there have been no biochemical or functional investigations of mucus glycoprotein secretion in patients with coeliac disease. The mucus barrier is an important factor in the protection of the intestinal epithelium from luminal aggressors ${ }^{5}$ and qualitative and quantitative changes in mucus glycoprotein synthesis and secretion have been associated with specific intestinal diseases. ${ }^{\text {ns }}$

Immunological factors have been shown to stimulate mucus glycoprotein secretion at pulmonary" ${ }^{\prime \prime}$ and gastrointestinal sites. " There is strong evidence from immunohistological and functional studies of raised immunological activity in the small intestinal mucosa of untreated coeliac patients. ${ }^{12}$.3 Enhanced mucosal immunological activity could well influence small intestinal glycoprotein biosynthesis. In this study we have investigated glycoprotein synthesis and secretion by small

Address for correspondence: Dr J E Crabtree, Department of Medicine. St James's University Hospital, Leeds I.SY 7TF.

Accepted for publication 21 February 1989 intestinal mucosa of patients with coeliac disease and normal subjects during short term in vitro culture.

\section{Methods}

COELIAC PATIENTS

Jejunal biopsies were obtained from 26 patients with coeliac disease using a Crosby capsule or a Quinton hydraulic multiple biopsy instrument. Thirteen were untreated ( 10 women, mean age $39 \cdot 1$ years, range 17-69) on normal diets at the time of biopsy. Jejunal biopsies from these patients showed subtotal villous atrophy on histological examination. Ten of the untreated patients have, to date, shown histological improvement of villous architecture on gluten free diets. The 13 treated coeliac patients $(11$ women, mean age 36.9 years, range $17-53$ ) who were studied, had been on gluten free diets for a minimum of six months at the time of biopsy. Biopsies from eight patients were histologically normal and five patients had partial villous atrophy.

CONTROL PATIENTS

Jejunal tissue was obtained from 19 control patients (mean age 34.6 years, range 17-60) undergoing investigation for possible coeliac disease. Multiple biopsies were also obtained from the second part of the duodenum of 39 patients at endoscopy. The duodenal and jejunal mucosae of all control patients were normal at histological examination. 
ORGAN CULTURE

Immediately after biopsy, jejunal tissue was divided into pieces for routine histology and in vitro culture, using aseptic techniques. Biopsies for culture were placed into culture medium consisting of RPMI 1640 containing $23.8 \mathrm{mM}$ sodium bicarbonate (Flow Laboratories Ltd., Rickmansworth, Herts.), $40 \mu \mathrm{g} /$ $\mathrm{ml}$ gentamicin and $10 \%$ heat-inactivated fetal calf serum (Sera-Lab Ltd., Crawley). Each biopsy (two per patient) was orientated mucosal surface upwards on sterile stainless steel grid positioned over the central well of an organ culture dish (Falcon) containing $1.6 \mathrm{ml}$ of culture medium. The biopsies were incubated in a $5 \% \mathrm{CO}_{2}$ humidified incubator at $37^{\circ} \mathrm{C}$. Duodenal biopsies were treated similarly.

GLYCOPROTEIN SYNTHESIS AND SECRETION

The incorporation of radiolabelled glucosamine into acid-precipitable glycoproteins was measured using modifications of the methods of MacDermott et al. ${ }^{14}$ Biopsies were cultured in duplicate in medium containing $5 \mu \mathrm{Ci}$ of $\mathrm{D}-\left[1-{ }^{3} \mathrm{H}\right]$-glucosamine hydrochloride (specific activity 5.8 Ci mmol; Amersham). At the end of culture, the biopsies were gently rinsed in medium devoid of radiolabel to remove surface mucus. The tissue was homogenised in $2 \mathrm{ml} 3 \cdot 3 \mathrm{mM} \mathrm{CaCl}_{2}$ at $4^{\circ} \mathrm{C}$. Two aliquots $(200 \mu \mathrm{l})$ of the homogenate were removed for determination of total protein by a modified Lowry method ${ }^{15}$ and the glycoproteins in a further aliquot $(1400 \mu \mathrm{l})$ were precipitated with $10 \%$ trichloroacetic acid (TCA) and $1 \%$ phosphotungstic acid (PTA) at $4^{\circ} \mathrm{C}$ overnight. After centrifugation $(10000 \mathrm{~g})$ the precipitate was washed three times with $10 \%$ TCA and $1 \%$ PTA to remove unincorporated glucosamine and twice with 1:1 chloroform-methanol to extract lipids. The dried acid-insoluble precipitate was solubilised in $1 \mathrm{ml}$ NCS (Amersham) and counted in liquid scintillation solution (Optiphase $X$ ) in a Packard Tricarb 400() liquid scintillation counter. To correct for quenching, the samples were counted against an internal standard and the results expressed as disintegrations per minute per $\mathrm{mg}$ biopsy protein (dpm/mg protcin).

The secreted radiolabelled glycoproteins were measured by precipitating with $10 \%$ TCA and $1 \%$ PTA the glycoproteins in the culture medium and the medium used to rinse the biopsy. The precipitates were processed and counted in a similar manner to tissue glycoproteins TCA-PTA precipitates. Control cultures of radiolabelled medium incubated with no biopsy tissue were similarly processed to correct for non-specific binding of radioactivity to fetal calf serum. Total incorporation of radiolabel into acid precipitable glycoproteins was determined by combining the tissue and secreted counts. Data are expressed as means standard errors (SE) of duplicate cultures. Analysis of variance was carried out using the Kruskall-Wallis test. Statistical comparisons between mean values were carried out using the Mann-Whitney U-test for non-parametric data.

\section{MORPHOLOGICAL STUDIES}

To examine the relationship between glycoprotein synthesis and secretion and goblet cell numbers in individual patients, morphometric analysis of histological sections of jejunal tissue adjacent to that used for culture was undertaken. Periodic acid-Schiff stained sections were projected onto graph paper using a Leitz projecting microscope from a fixed distance. The area of the longitudinally sectioned biopsies from the epithelium to the submucosa was outlined and the number of goblet cells recorded. The area of the section was determined by comparison of the weight of the outlined area on the graph paper to that of a standard area determined by a graticule calibration slide. Triplicate or quadruplicate counts of non-overlaping areas were made of appropriately longitudinally sectioned biopsies and the results expressed as goblet cells $/ 10^{\mathrm{h}} \mu \mathrm{m}^{2}$ of mucosa. Goblet cell numbers were also expressed per unit length $(10 \mathrm{~mm})$ of epithelium.

\section{Results}

The incorporation of $\mathrm{H}$ glucosamine into glycoproteins by histologically normal duodenal tissue during 24 and 48 hours culture in vitro is shown in the Table. The total incorporation into tissue and secreted glycoproteins appeared to be linear over a 48 hour culture period. The counts associated with the tissue fraction increased between 24 and 48 hours culture suggesting continued glycoprotein synthesis. The percentage of radiolabelled glycoproteins secreted into the culture medium increased with the period of culture, $27 \%$ and $42.9 \%$ of the radiolabel being associated with secreted glycoproteins at 24 and 48 hours respectively.

Table Incorporation of 'H glucosamine into tissue and secreted glycoproteins by duodenal biopsies during culture in vitro

\begin{tabular}{|c|c|c|c|c|}
\hline \multicolumn{5}{|c|}{$\begin{array}{c}H \text { glacosamine incorporation DPM/mg protein } \times 10^{\circ} \\
(\text { Mean }(S E))\end{array}$} \\
\hline & $n$ & Tissue & Secreted & $\begin{array}{l}\text { Total } \\
\text { incorporation }\end{array}$ \\
\hline \multicolumn{5}{|c|}{ Culture (h) } \\
\hline 24 & 27 & $14+(7 \cdot 4)$ & $5.3 .5(4.8)$ & $197.5(8.7)$ \\
\hline 48 & 12 & $225(36 \cdot 7)$ & $175.5(30)$ & $4(0) \cdot 5(61 \cdot 8)$ \\
\hline
\end{tabular}






Fig. 1 Total incorporation of 'H glucosamine into acid precipitable glycoproteins by normal jejunal mucosa and mucosa from treated (TC) and untreated (UTC) coeliac patients during 24 hours culture in vitro.

The total incorporation of exogenous ${ }^{3} \mathrm{H}$ glucosamine into tissue and secreted glycoproteins by coeliac and normal jejunal tissue over 24 hours culture in vitro is shown in Figure 1 . The total incorporation by untreated coeliac mucosa, 427 (34) $\mathrm{dpm} \times 10^{3} / \mathrm{mg}$ protein (mean $\left.(\mathrm{SE})\right)$, was significantly greater $(p<0.001)$ than that of histologically normal mucosa, 248 (13) dpm $\times$ $10 \% \mathrm{mg}$ protein. Glycoprotein synthesis and secretion by treated coeliac mucosa, $265(15 \cdot 3) \mathrm{dpm} \times 10^{3} / \mathrm{mg}$ protein, was not significantly different from that of normal jejunal tissue, but was significantly lower $(p<0.01)$ than that of untreated coeliac mucosa.

The proportion of ${ }^{3} \mathrm{H}$ glucosamine incorporated into tissue and secreted glycoproteins is shown in Figure 2. Biopsies from untreated coeliac patients incorporated significantly higher amounts $(p<0 \cdot 05)$ of radiolabel into tissue glycoproteins than normal or treated coeliac mucosa. The secretion of radiolabelled glycoproteins by untreated coeliac mucosa was also significantly greater than normal $(p<0 \cdot 001)$ and treated coeliac $(\mathrm{p}<0 \cdot 01)$ tissue. In untreated coeliac mucosa, $39.5 \%$ of the ${ }^{3} \mathrm{H}$ glucosamine incorporated into acid precipitable glycoproteins over a 24 hour period was secreted. The percentage of radiolabelled glycoproteins secreted by normal and treated coeliac tissue was significantly lower

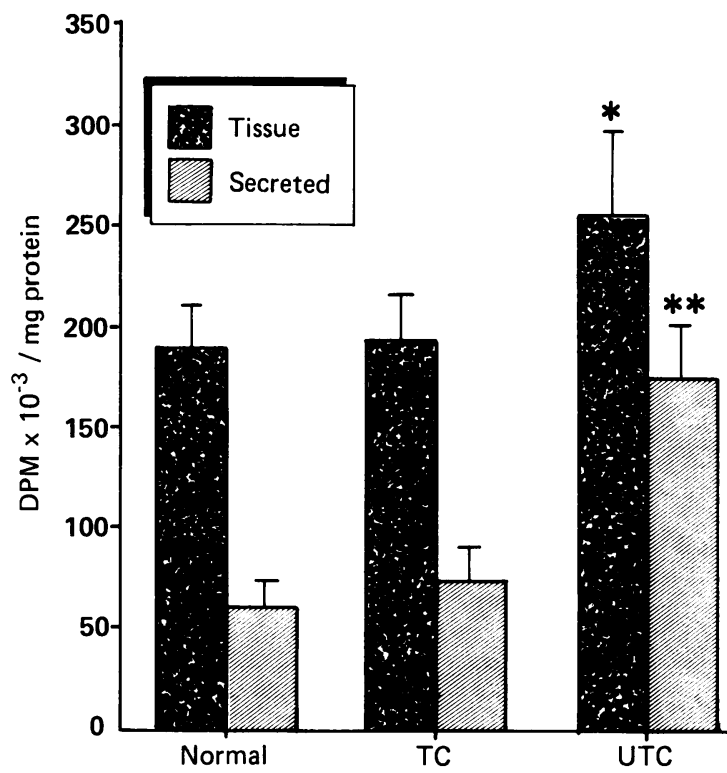

Fig. 2 Incorporation of ' $H$ glucosamine into tissuc and secreted glycoproteins by normal jejunal mucosa and mucosa from treated (TC) and untreated (UTC) coeliac patients during 24 hours in vitro culture. ${ }^{*} p<0 \cdot 05$ from controls $* * p<0.01$ from $T C$ and $<0.001$ from controls.

( $p<0 \cdot 05$ ), being $24 \%$ and $27 \%$ respectively.

There was a significant correlation $(p<0.05)$ between the total ${ }^{\mathrm{H}} \mathrm{H}$ glucosamine incorporation into glycoproteins in histologically normal jejunal tissue and the goblet cell numbers per unit area of mucosa in histological sections of adjacent tissue (Fig. 3). The mean goblet cell numbers $/ 10^{h} \mu \mathrm{m}^{2}$ in histologically normal mucosa were not significantly different from those in untreated coeliac mucosa being $358(22 \cdot 3)$ and 388 (24) respectively. When goblet cell numbers were expressed per unit length of epithelium (10) $\mathrm{mm}$ ), the mean cell number in untreated cocliac mucosa $(299.5 \quad(13.9))$ was significantly higher $(\mathrm{p}<0.01)$ than that of histologically normal mucosa $(223 \cdot 5(12 \cdot 9))$.

\section{Discussion}

The results show that over 24 hours culture in vitro, untreated coeliac mucosa synthesises and secretes greater quantities of glycoproteins than histologically normal jejunal mucosa. The use of radiolabelled sugars to measure gastrointestinal glycoprotein production is a well established technique ${ }^{7+110}$ and is thought largely to be an indication of mucus glycoprotein secretion. ${ }^{14}$ Small intestinal brush border membrane proteins have, however, been shown to 


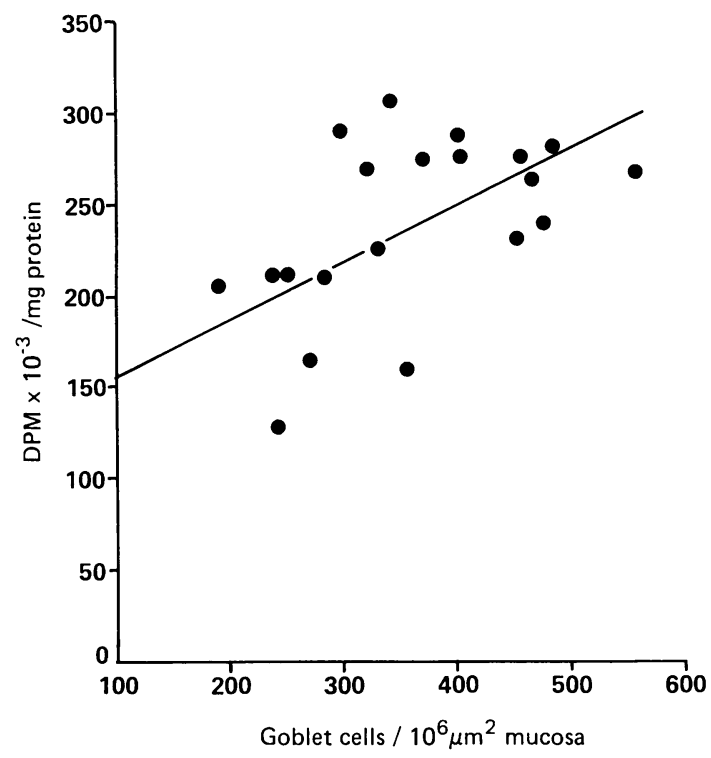

Fig. 3 Relationship between total incorporation of $\mathrm{H}$ glucosamine into glycoproteins during 24 hours culture and goblet cell numbers per unit area in histologically normal jejunal tissue. $p<0 \cdot(05, r=0.533$.

incorporate radiolabelled glucosamine during culture. ${ }^{7}$ In the latter study the majority of radiolabelled glycoproteins were in a high molecular weight fraction with no brush border enzyme activity. ${ }^{17}$ The reduction in intestinal brush border enzyme activities in untreated cocliac patients ${ }^{1 \times}$ implies that the enhanced glycoprotein synthesis observed in this group is not attributable to labelling of such components, although it could be indicative of increased cell turnover. 'Furthermore, evidence from animal studies suggests that differentiated upper villous enterocytes incorporate more labelled sugar precursors into membrane glycoproteins than undifferentiated crypt cells." Previous in vitro studies with "C-labelled leucine have demonstrated enhanced protein synthesis in untreated cocliac mucosa $a^{21}$ and the incorporation of radiolabel during 24 hours culture was linear for both normal and cocliac mucosa suggesting no differential survival of tissue during culture in vitro.

The results of this study show a significant correlation between $\mathrm{H}$ glucosamine incorporation into glycoproteins in histologically normal tissue and goblet cell numbers $/ 10^{\circ} \mu \mathrm{m}^{2}$ mucosa in individual patients. Whilst the number of goblet cells per unit length of epithelium was significantly increased in untreated coeliac mucosa, the changes in surface to mucosal area ratio associated with villous atrophy resulted in no marked increases in goblet cell number when expressed per unit area of mucosa. These observations suggest that the increased glucosamine incorporation in untreated mucosa (expressed as $\mathrm{dpm} / \mathrm{mg}$ biopsy protein) could in part be a result of an increase in the rate of mucus glycoprotein biosynthesis at the cellular level. While local immunoglobulin production is increased in coeliac disease, the extent of glycosylation of immunoglobulins " is unlikely to account for the markedly increased incorporation of $\mathrm{H}$ glucosamine into glycoproteins over the 24 hour culture period. Alternatively, the differences in incorporation could reflect changes in precursor pool sizes, with histologically normal mucosa having a larger intracellular pool of unlabelled glucosamine. Free glucosamine, however, had not been found in intestinal tissue. ${ }^{\text {?" }}$

Several immunological factors could contribute to the enhanced secretion of radiolabelled glycoproteins observed in untreated coeliac patients. Immune complexes, "macrophage products" and the anaphylatoxin $\mathrm{C}^{3} \mathrm{a}^{2+}$ have all been shown to stimulate mucus glycoprotein secretion by intestinal or pulmonary tissue. $T$ lymphocytes have also been implicated in intestinal goblet cell hyperplasia in helminth infections in rats. ${ }^{25}$ The increased activation of $\mathrm{T}$ lymphocytes in untreated cocliac mucosa' 1: may induce changes in goblet cell maturation or differentiation. $T$ lymphocyte products have recently been shown to modify epithelial differentiation, enhancing the expression of HLA-DR on intestinal epithelial cell lines ${ }^{27}$ and fetal intestinal epithelium ${ }^{2 x}$ in vitro.

The basal rate of mucus secretion can also be modified by endogenous neurotransmitters - for example, acetylcholine, ${ }^{21}$ and vasoactive amines such as 5-hydroxytryptamine "in as well as numerous external secretagogues.

Whilst our results show quantitative changes in mucus glycoprotein secretion in untreated cocliac mucosa, relatively little is known about the biochemical nature of mucus in coeliac disease. Certainly in untreated patients there is an increase in intestinal permeability," suggesting that the enhanced mucus secretion does not impede the uptake of marker molecules. A recent histological study has reported changes in lectin binding characteristics of goblet cells of children with coeliac disease, implying alterations in oligosaccharide side chains of mucus glycoproteins. In situations in which increased mucus glycoprotein secretion is observed, qualitative changes in the released mucus frequently occur. This, therefore, may have direct relevance to the pathogenesis of coeliac disease, accounting for the observed increase in intestinal permeability and perhaps also some of the recognised immune abnormalities in this condition. 
This work was supported by the Medical Research Council. We would particularly like to thank Dr J Findlay. Dr A Manning and the staff of the Gastroenterology Departments of Bradford Royal Infirmary and St James's University Hospital for their cooperation and Miss S Walker-Mernagh for her excellent technical assistance.

\section{References}

I Shiner M. Vltrastructure of the small intestinal mucosa. Normal and disease-related appearances. Berlin: Springer-Verlag. 1983:61-94.

2 Phillips AD. Smith MW. Walker-Smith JA. Selective alteration of brush-border hydrolases in intestinal discases in childhood. (lin Sci 1988: 74: 193-200.

3 Wright N. Watson A. Morley A. Appleton D. Marks J. Douglas $A$. The cell cycle time in the flat (avillous) mucosa of the human small intestine. Gut 1973: 14: 60)3-6.

+ Arnaud-Battandier F. Cerf-Bensussan N. Amsellem R. Schmitz J. Increased HLA-DR expression by enterocytes in children with celiac disease. Gastroenterology 1986: 91: 1206-12.

5 Miller HRP. Gastrointestinal mucus, a medium for survival and for elimination of parasitic nematodes and protozoa. Parasitology 1987: 94: S77-S100.

6 Filipe MI. Mucins in the human gastrointestinal epithelium: a review. Invest (ell Pathol 1979: 2: $195-216$.

7 Smith AC. Podolsky DK. Biosynthesis and secretion of human colonic mucin glycoproteins. J Clin Invest 1987: 80: $300-7$.

\& Cope GF. Heatley RV. Kelleher J. Axon ATR. In vitro mucus glycoprotein production by colonic tissuc from patients with ulcerative colitis. Gui 1988: 29: 229-34.

9 Marom Z. Shelhamer JH. Kaliner M. Human monocytederived mucus secretagogue. I Clin In'est 1985: 75: $191-8$.

10 Marom Z. Shelhamer JH. Bach MK. Morton DR. Kaliner M. Slow-reacting substances, leukotriences $C_{4}$ and $\mathrm{D}_{4}$ increase the release of mucus from human airways in vitro. Am Rev Respir Dis 1982: 126: 449-4.51.

11 Lake AM. Bloch KJ. Sinclair KJ. Walker WA. Anaphylactic release of intestinal goblet cell mucus. Immunology 1980: 39: 173-8.

12 Malizia G. Trejdosiewicz LK. Wood GM. Howdle PD. Janossy G. Losowsky MS. The microenvironment of coeliac discase: T cell phenotypes and the expression of the T2 'T blast' antigen by small bowel lymphocytes. Clin Exp Immunol 1985: 60: 437-46.

1.3 Crabtree JE. Heatley RV. Losowsky MS. Immunoglobulin secretion by isolated intestinal lymphocytes: spontancous production and $\mathrm{T}$-cell regulation in normal small intestine and in patients with cocliac disease. (iut 1989: 30: 347-.54.

14 MacDermott RP. Donaldson RM. Trier JS. Glycoprotein synthesis and secretion by mucosal biopsies of rabbit colon and human rectum. J Clin Invest 1974; 54: $54.5-54$.
15 Peterson GL. A simplification of the protein assay method of Lowry et al which is more generally applicable. Anal Biochem 1977: 83: 346-56.

16 Yeomans ND, Millar SJ. Synthesis and secretion of glycoproteins by mucosa of rat gastric antrum in organ culture. Dig Dis Sci 1980; 25: 295-301.

17 Hauri HP. Kedinger M. Haffen K. et al. Biosynthesis of brush border glycoproteins by human small intestinal mucosa. Biochim Biophys Acta 1977; 467: 327-39.

18 Falchuk ZM. Geghard RL. Sessoms C. Strober W. An in vitro model of gluten-sensitive enteropathy. Effect of gliadin on intestinal epithelial cells of patients with gluten-sensitive enteropathy in organ culture. I Clin Invest 1974: 53: 487-5(0).

19 Weiser MM. Intestinal epithelial cell surface membrane glycoprotein synthesis 1 . An indicator of cellular differentiation. J Biol Chem 1973; 248: 2563-41.

20) Jones PE. L'Hirondel CL. Peters TJ. Protein synthesis by cultured jejunal mucosa from control subjects and patients with cocliac discase. (jut 1981: 22: 623-7.

21 Wood GM. Shires S, Howdle PD, Losowsky MS. Immunoglobulin production by cocliac biopsics in organ culture. Gitt 1986: 27: 1151-60.

22 Mestecky J. Mc(ihec JR. Immunoglobulin A $(\operatorname{Ig} A)$ : Molecular and cellular interactions involved in IgA biosynthesis and immune response. Adv Immunology 1987: 40: 15.3-24.5.

23 Lukie BE. Forstner GG. Synthesis of intestinal glyeoprotein. Incorporation of $\left(1-{ }^{\prime \prime} C\right)$ glucosamine in vitro. Biochim. Biophys Acta 1972; 261: 353-64.

24 Marom Z. Shelhamer J, Berger M. Frank M, Kaliner M. Anaphylatoxin (3a enhances mucous glycoprotein release from human airways in vitro. $J$ Exp Med 1985: 161: $6.57-68$.

25 Miller HRP. Nawa Y. Immune regulation of intestinal goblet cell differentiation. Nouv Rev Fr Hematol 1979; 21: $31-45$.

26 Miller HRP, Nawa Y, Parish CR. Intestinal goblet cell differentiation in Nippostrongylus-infected rats after transfer of fractionated thoracic duct lymphocytes. Int Arch Allergy Appl Immunol 1979; 59: 281-5.

27 Sollid LM. Brandtzacg P. Kvale D. Gaudernack (;. Scott $H$. Thorsby E. T cell-epithelium interactions in relation to gut immunity. Monogr Allergy 1988; 24: 6()$-5$.

28 MacDonald TT. Weinel A. Spencer J. HLA-DR expression in human fetal intestinal epithelium. (jut 1988: 29: 1342-8.

29 Specian RD, Neutra MR. Mechanism of rapid mucus secretion in goblet cells stimulated by acetylcholine. $J$ (ell Biol 1980): 85: 626-4).

30) Bradbury JE. Black JW. Wyllic JH. Stimulation of mucus output from rat colon in vivo. Eur J Pharmacol 1980: 68: 417-25.

31 Hamilton I, Cobden I, Rothwell J, Axon ATR. Intestinal permeability in cocliac discase: the responsc to gluten withdrawal and single dose gluten challenge. (iuil 1982: 23: 202-210.

32 Barresi G. Tuccari G, Tedeschi A. Magazzu G. Lectin binding sites in duodeno-jejunal mucosac from cocliac children. Histochemistry 1988: 88: 10.5-12. 